\title{
Locke's Natural and Religious Epistemology
}

(formerly titled "Locke on Reason, Faith, and Miracles")

Shelley Weinberg

Journal of the History of Philosophy - forthcoming

\begin{abstract}
In this paper, I am outlining a new, and perhaps controversial, account of Locke's epistemology. The common denominator in any act of assent in both the natural and religious epistemologies is the regulating role of reason. Key to the regulating role of reason is the requirement that any cognitive achievement, whether of knowledge, probability, or matter of faith, meets epistemic conditions at different stages or from different points of view. By employing the same justificatory structure throughout his epistemology, Locke offers a way in which reason can be seen to go as far as it can to justify itself (its reliability as well as its scope) from within its own natural limitations.
\end{abstract}

Keywords Locke, epistemology, reason, faith, knowledge, probability, miracles

\section{Introduction}

In the Correspondence, Stillingfleet objects that Locke's definition of knowledge, by limiting certainty to the perception of the agreement or disagreement of ideas, "lessens the credibility of faith." ${ }^{1}$ Locke replies that his definition of knowledge doesn't affect the credibility of an article of faith at all, for faith and knowledge are entirely different cognitive acts:

The truth of the matter of fact is in short this, that I have placed knowledge in the perception of the agreement or disagreement of ideas. This definition of knowledge, your lordship said, "might be of dangerous consequence to that article of faith, which you have endeavored to defend." This I denied, and gave this reason for it, viz. that a definition of knowledge, whether good or bad, true or false definition, could not be of ill or any consequence to an article of faith: because a definition of knowledge, which was one act of the mind, did not at all concern faith, which was another act of the mind quite distinct from it. (Works IV: 282)

What sort of act of the mind is faith such that it is "quite distinct" from knowledge? The most obvious reply is that it is what Locke would call a probable judgment, which is an act of the mind

\footnotetext{
${ }^{1}$ Locke (1823: IV, 283). All additional references to The Works of John Locke will be in the paper by volume and page number.
} 
wherein we take or suppose ideas to agree when we don't perceive them to agree (IV.xiv.4). ${ }^{2}$ But this can't be the answer, for Locke also seems to think that where both knowledge and probable judgment are grounded in reason, faith is not. First, chapter 18 of Book IV is entitled "Of Faith and Reason, and their Distinct Provinces" (4.18). The failure to understand the distinct provinces of faith and reason has not served us well, says Locke, having "possibly...been the cause, if not of great disorders, yet at least of great disputes, and perhaps mistakes in the world. For till it be resolved how far we are to be guided by reason, and how far by faith, we shall in vain dispute, and endeavor to convince one another in matters of religion" (4.18.1). Had we a better grip on the provinces of faith and reason, we would have saved ourselves from needless disputes due to an appeal to radically different sources of evidence.

Faith, for Locke, seems to be something different from either knowledge or probability because it is assent to a proposition that has its source, or evidence, in neither reason nor our natural faculties of sensation and reflection:

There being many Things, wherein we have very imperfect Notions, or none at all; and other Things, of whose past, present, or future Existence, by the natural Use of our Faculties, we can have no Knowledge at all; these, as being beyond the Discovery of our natural Faculties, and above Reason, are, when revealed, the proper matter of Faith. Thus that part of the Angels rebelled against GOD, and thereby lost their first happy state: And that the dead shall rise, and live again: These, and the like, being beyond the Discovery of Reason, are purely Matters of Faith; with which Reason has, directly, nothing to do. (IV.xviii.7)

Proper matters of faith, says Locke, are "beyond the discovery of reason; they are "above reason."3 But passages like this can be potentially misleading, for one might think that reason

\footnotetext{
${ }^{2}$ Heretofore, I will refer to Locke's Essay concerning Human Understanding by book, chapter, and section number.

3 It is an interesting question exactly what Locke means by "above" reason. In the passage above from IV.xviii.7, "above reason" seems to suggest that faith is assent to a proposition that we cannot discover through our natural faculties. But in IV.xvii.23 where he makes that same distinction, he also seems to suggest that "above reason" means better than reason, since the attitude of assent is greater: "Above Reason also may be taken in a double sense, viz. either as signifying above probability or above certainty." It could be that revealed truths, if we can know them to be revealed, have higher epistemic standing because their source is in God - they are divinely guaranteed. The standard view, which we find in both Aquinas and Leibniz is that propositions "above reason" include component parts that are fully comprehended and known to divine reason, but are either incomprehensible or inevident to
} 
(and our natural faculties) play no role at all in matters of faith. Not only would that be woefully un-Lockean, but it would fly in the face of passages of this sort: "Faith is nothing but a firm Assent of the Mind: which if it be regulated, as is our Duty, cannot be afforded to any thing, but upon good Reason; and so cannot be opposite to it" (IV.xvii.24). It would seem that Locke can't have it both ways - that faith is "above reason," and yet also somehow answerable to reason. My first task in the paper is to show how faith is different from either knowledge or probability, yet at the same time assent to a proposition "afforded...upon good reason."

A second, and more ambitious, question I attempt to answer is how, in spite of this difference between faith and reason, the structure of assent to propositions of faith, namely Locke's religious epistemology, is fully consistent with the structure of his natural epistemology. I think we can draw an analogy between how we come to assent to true propositions (perceive agreements) in knowledge resulting in different degrees of certainty, how we come to affirm probable judgments resulting in what Locke calls the "degrees of assent," and how we come to affirm revealed propositions resulting in faith. ${ }^{4}$ Although matters of faith are "above reason," in that what we assent to does not have its source in our natural faculties (the evidence is nonnatural), the justificatory structure is the same across all of Locke's epistemology. The common denominator in all three kinds of assent (knowledge, probability, and faith), or so I will argue, is the regulating role of reason. In addition, I will argue that key to the regulating role of reason in Locke's epistemology generally is the requirement that any cognitive achievement, whether of knowledge, probability, or matter of faith, meets epistemic conditions at different stages or from different points of view. With this argument I am outlining a new, and perhaps controversial,

human reason. In addition, propositions "above reason" are not internally inconsistent or inconsistent with any truths of reason. I thank Kristen Irwin for help with this distinction.

${ }^{4}$ I am thinking of faith here as opposed to Locke's understanding of "enthusiasm," which is belief that a proposition is revealed by God with no justification that it is revelation. 
account of Locke's epistemology, but one that employs the same justificatory structure in each

case of assent.

One might wonder what work is done in Locke's overall epistemological project by drawing an analogy between Locke's natural and religious epistemologies. After all, if we can't have knowledge of religious matters, then our assent is simply a matter of opinion. As we see throughout Locke's work, and especially in the Essay and the writings on toleration (and his subsequent defenses of it), Locke was clearly engaged in the task of establishing the difference between knowledge and opinion, such that we do not make claims to know more than we actually do.

Locke begins the Essay with this statement of its purpose and design:

This, therefore, being my Purpose to enquire into the Original, Certainty, and Extent of human Knowledge, together with the Grounds and Degrees of Belief, Opinion, and Assent;... It shall suffice to my present Purpose, to consider the discerning Faculties of a Man, as they are employ'd about the Objects which they have to do with: And I shall imagine I have not wholly misemploy'd my self in the Thoughts I shall have on this Occasion, if, in this Historical, plain Method, I can give any Account of the Ways whereby our Understandings come to attain those Notions of Things we have, and can set down any Measures of the Certainty of our Knowledge, or the Grounds of those Perswasions, which are to be found amongst Men, so various, different, and wholly contradictory; and yet asserted somewhere or other with such Assurance, and Confidence, that he that shall take a view of the Opinions of Mankind, observe their Opposition, and at the same time, consider the Fondness and Devotion wherewith they are embrac'd, the Resolution and Eagerness, wherewith they are maintain'd, may perhaps have Reason to suspect, That either there is no such thing as Truth at all; or that Mankind hath no sufficient Means to attain a certain knowledge of it. (I.i.2)

First, Locke will consider our natural faculties as they are employed about "the objects they have to do with" to "set down the measures" of the certainty of our knowledge as well as give an account of the ways in which we come to be persuaded of our beliefs. I take Locke's question to be something like this: Given what we seem to know with certainty, to what extent or degree are our natural faculties actually capable of certain knowledge, and where we do have certainty what are the measures, grounds, or justificatory criteria for those cognitive achievements? In addition, 
given how persuaded we can be of our own opinions, even when they contradict the opinions of others, how do we not conclude either that there is no truth to be had or that we are incapable of knowing it? So, similarly, what are the measures, grounds, or justificatory criteria guiding our assent to propositions that are less than certain?

It is therefore worth while to search out the bounds between opinion and knowledge; and examine by what measures, in things whereof we have no certain knowledge, we ought to regulate our assent and moderate our persuasion. (I.i.3)

But Locke's consideration of the measures by which we regulate our assent was not confined to his natural epistemology. After concluding the account of knowledge and probability, he includes a chapter (IV.xviii) on religious epistemology (the status of our beliefs asserted to be based in divine revelation) entitled "Of Faith and Reason, and their distinct provinces." For the fourth edition (1700) he adds a chapter (IV.xix), "Of Enthusiasm," to distinguish an unreasoned claim to have received the word of God from justifiable claims to divine revelation, and in 1701/1702 (published posthumously in 1706) he writes $A$ Discourse of Miracles explaining how miracles serve to justify non-naturally communicated propositions, either directly or indirectly. In the intervening years he engages in exacting Biblical interpretation in the Reasonableness of Christianity (1695) to show what of orthodox Christian belief can lay claim to rational justification. ${ }^{5}$ So when Locke says that his task in the Essay is to lay out the grounds of opinion and knowledge and when we do not have knowledge figure out how we should "regulate our assent and moderate our perswasion," I suggest he means not just to show that matters of religious faith fall into the realm of opinion, but that figuring out what is epistemically

\footnotetext{
${ }^{5}$ Also worth consideration are Immediate Inspiration (1687) and An Essay for the Understanding of St Paul's Epistles by Consulting St Paul himself (published posthumously in 1707). The latter essay formed the preface to Notes and Paraphrases on the Epistles of St Paul and provides an empirical hermeneutics for interpreting the Pauline writings. (See Locke's letter to Peter King, 15 October 1704, for his express desire that it should be printed.) See Nuovo (2002: xxxiii-xxxix) for more on these writings.
} 
warranted, in any case, requires understanding the justificatory criteria by which we regulate our assent.

What underwrites Locke's entire epistemological project, or so I will argue, is a consistent understanding of how reason regulates all of our epistemic achievements. And what underwrites that understanding is the appeal to reason as justifiable from within its own limits. Whether we are considering the epistemic status of a religious belief based in revelation, a probable belief based in experience, or the certainty of the truth of a mathematical demonstration, there is a natural epistemic procedure (the meeting of epistemic conditions) based in the employment of reason itself. But if reason is to regulate what we can know and believe, then there must be an account of the derivation of its entitlement to do so. Showing that entitlement requires us to understand how reason, from within itself, establishes consistent guidelines for knowledge and justified belief across all of Locke's epistemology. Thus we have to also look into the justificatory criteria and how they are employed in the religious epistemology. That, I suggest, is to understand the ground and measures, namely the rational regulation, of all of our epistemic achievements.

Put another way, perhaps the interpretation of epistemic conditions in Locke's overall epistemology I am offering can be seen as finding a middle road between two claims. One by Ayers (1991: 123) that Locke might be guilty of something like the Cartesian circle in relying on the goodness of God not to give us deceptive faculties and then offering us a proof for the existence of God that he thinks is as good anything in Euclid. The other by Jolley (2007: 454) that we can press the question whether reason is a reliable faculty at all, or whether it "systematically distort(s) reality, like the curved mirrors in an amusement park." Jolley defends against this worry by arguing that in all fairness Locke's concern is the scope and not the 
reliability of reason. Although it does not eliminate all worry that the faculty of reason can be systematically wrong, my interpretation does move the ball fairly far forward in offering a way in which reason can be justified from within itself - that Locke's overall epistemology (natural and religious) goes as far as it can to justify itself (its reliability as well as its scope) from within its own natural limitations.

One caveat: in this paper, insofar as I am making the case for structurally analogous epistemic conditions in Locke's religious epistemology, I will focus on cases of original revelation and on cases of traditional revelation in which God's original revelation is transmitted directly to others, that is, on cases in which there is direct evidence of revelation provided by the performance of miracles. Fleshing out what I believe to be a very interesting and consistent story to tell with respect to traditional revelation as transmitted through the reading of scripture will have to wait for another time.

Let's begin with a little background.

\section{Knowledge and Probability}

Locke maintains a firm line between knowledge and probable judgment (opinion). Knowledge, Locke defines as "the perception of the connexion and agreement, or disagreement and repugnancy of any of our Ideas...Where this Perception is, there is Knowledge, and where it is not, there, though we may fancy, guess, or believe, yet we always come short of Knowledge" (IV.i.2). ${ }^{6}$ Locke can be seen to confirm his definition of knowledge in his claims that all knowledge is propositional. That is, the agreeing ideas are constituents of mental propositions. ${ }^{7}$

\footnotetext{
${ }^{6}$ Hereafter, for ease, I will shorten the definition of knowledge to "the perception of an agreement of ideas."

${ }^{7}$ In II.xxxiii.19, for example, we find, “...our Knowledge, which all consists in Propositions.” See also IV.v.1 and Locke, Works, iv: 357.
} 
Perceiving an agreement of ideas counts as certain knowledge; not perceiving one, even if it is there, is probable conjecture (IV.ii.2).

Knowledge, Locke thinks, comes in three degrees of certainty: intuitive, demonstrative, and sensitive. Intuitive knowledge, with the highest degree of certainty, is the immediate perception of an agreement; demonstrative knowledge, a little less certain than intuitive, requires an intervening idea(s), in order to perceive the agreement. It is knowledge by proof where each step in the proof is known intuitively. Sensitive knowledge of the existence of external objects is less certain than demonstrative, but meeting the definition of knowledge as the perception of an agreement of ideas still counts as knowledge with a degree of certainty rather than probable judgment, for Locke at least. ${ }^{8}$ Probability is an analog to demonstrative knowledge in that it always has the structure of a proof, but an incomplete one. But in probable judgment as opposed to knowledge, "That which makes me believe," he says, "is something extraneous to the thing I believe" (IV.xv.3). Those extraneous inducements to believe are twofold: "the conformity of any thing with our Knowledge, Observation, and Experience" (IV.xv.4) and "The Testimony of others, vouching their Observation and Experience" (IV.xv.4). Despite these differences, both knowledge and probable judgment admit of a scale of qualitative degrees of assent: in knowledge there are the three degrees of certainty and in probable judgment there is anything from “assurance" (IV.xvi.6) and "confidence" (IV.xvi.7) to "Belief, Conjecture, Guess, Doubt, Wavering, Distrust, Disbelief, etc." (IV.xvi.9).

The important point I wish to take away from this very brief description of Locke's theories of knowledge and probability is that there is structural similarity in the accounts. In both cases, there is 1.) the cognitive achievement (knowledge or probable judgment (the perception)), 2.) the

\footnotetext{
${ }^{8}$ Although recent scholarship leans fairly heavily in this direction, it is not uncontroversial. See note 24.
} 
evidence for it (the true proposition or the demonstrative proof in knowledge and the argument based in either experience or testimony in probable judgment), and 3.) the qualitative attitude of assent (a degree of certainty in knowledge and a range of, say, credences in probable judgment). I will argue, first, that there is a similar structure in matters of faith: there is the cognitive achievement, the evidence provided, and an attitude of assent. Second, even though Locke sees judgments of faith as not discoverable by our natural faculties, I will argue that Locke's religious epistemology is fully consistent with, and, importantly, quite akin to what I see as, his natural epistemology. For our assent to a proposition of faith, like the certainty with which we have different forms of knowledge and the degrees of assent in probable judgment, is due to different levels or stages of cognitive achievement. Moreover, in all three cases, the stages of cognitive achievement (the meeting of epistemic conditions) reveal the importance of the regulating role of reason in both Locke's natural and religious epistemologies.

\section{Judgments of Faith}

Locke seems to think that judgments of faith fall into neither the category of knowledge nor of probability. ${ }^{9}$ What is the distinction Locke means to draw? Matters of faith, as we saw, are “above reason." In IV.xvii.23, Locke distinguishes claims into those that are "according to, above, and contrary to Reason":

\footnotetext{
9 Ayers (1991, I: 84) notes that other seventeenth century figures saw faith as neither knowledge nor opinion: "[L]ike Arnauld, Gassendi saw 'faith' as a separate type of judgement. Yet he made the point that we can and often do have faith and opinion about the same things, since the acceptance of (at any rate, human) authority will involve an opinion as to the speaker's veracity in saying what he does." Jolley (2007: 438) may disagree when he says, "Locke is not to be numbered among those thinkers who regard religious faith as sui generis." Wolterstorff (1996: 124) seems to split the difference between these two views, when he claims "A three-fold distinction.... in how human beings hold beliefs about God. Sometimes they hold them as matters of opinion, on the basis of tradition or whatever. Sometimes they hold them as that special form of opinion which is faith. And sometimes they know them - demonstratively, however, not intuitively (IV,iii,21; IV,x)." On p. 125-126, Wolterstorff continues, "Let us be clear that it is not the proposition that God has revealed $P$ which is the object of faith...Rather it is $\mathrm{P}$ itself, the proposition one believes to have been revealed by God, that is the object of faith."
} 
1. According to Reason are such Propositions, whose Truth we can discover, by examining and tracing those Ideas we have from Sensation and Reflection; and by natural deduction, find to be true, or probable. 2. Above Reason are such Propositions, whose Truth or Probability we cannot from Reason derive from those Principles. 3. Contrary to Reason are such Propositions, as are inconsistent with, or irreconcilable to our clear and distinct Ideas. Thus the Existence of GOD is according to Reason; the Existence of more than one GOD, contrary to Reason; the Resurrection of the Dead, above Reason. (IV.xvii.23)

Where knowledge and probability have their sources in our natural faculties and require the use of reason to discover truths from what is given in sensation and reflection, ${ }^{10}$ judgments of faith have their source in divine revelation. Revealed truths are imparted to us, either directly or indirectly, through divine communication. Locke explains, "[A] Matter of Faith being only Divine Revelation, and nothing else, Faith, as we use the Word, (called commonly Divine Faith) has to do with no Propositions, but those which are supposed to be divinely revealed" (IV.xviii.6). Faith ("Divine Faith") has to do with propositions for which the source is nonnatural - given not via sensation or reflection. Here is another passage in which Locke draws the distinction between reason and faith:

Reason therefore..., as contradistinguished to Faith, I take to be the discovery of the Certainty or Probability of such Propositions or Truths, which the Mind arrives at by Deductions made from such Ideas, which it has got by the use of its natural Faculties, viz. by Sensation or Reflection.

Faith, on the other side, is the Assent to any Proposition, not thus made out by the Deductions of Reason; but upon the Credit of the Proposer, as coming from GOD, in some extraordinary way of Communication. This way of discovering Truths to Men we call Revelation. (IV.xviii.2)

Although faith and probability both rely on testimony, still Locke is drawing a distinction on the basis of the source of the proposition, whether in revelation (an "extraordinary way of Communication") or in experience ("by Sensation or Reflection”).

Surely, as Locke says, "the same Truths may be discovered, and conveyed down from Revelation, which are discoverable to us by Reason" (IV.xviii.4). For example, one person might

\footnotetext{
${ }^{10}$ I am using "reason" here in a general sense comprising our natural faculties of knowledge and belief, not in the more narrow sense of "casting about" for intervening ideas to construct a demonstration. See also Jolley (2007: 442).
} 
learn a moral truth, say, that murder is wrong, by reading the Bible while another learns it as the result of demonstrating the truth of that proposition. In the first case, one makes a judgment of faith; in the second there is an act of knowing. ${ }^{11}$ Also, it seems to be the case that the same proposition can be the content of a judgment of faith and of a probable judgment. Not knowing anything about the Bible or what is written in it, and without inquiring of my friend the source of her testimony, I may doubt her proposition that the dead are resurrected, which would be a probable judgment on my part. Or I can discover it for myself in the Bible, a book I believe to contain God's revelation, which would result in a judgment of faith. ${ }^{12}$ Nevertheless, as we saw in the passage from IV.xviii.7 above, Locke distinguishes reason (knowledge and probability) from what he calls "the proper Matter of Faith" or, as we see in IV.xviii.9, what is "purely" a matter of faith:

Whatever Proposition is revealed, of whose Truth our Mind, by its natural Faculties and Notions, cannot judge, that is purely Matter of Faith, and above Reason. (IV.xviii.9)

Here Locke seems to carve out pure matters of faith from, say, ordinary faith or probability, as propositions that we can perhaps understand but cannot know or judge the truth of through the employment of our natural faculties. ${ }^{13}$ Consider also this passage:

\footnotetext{
${ }^{11}$ Locke placed "Morality amongst the Sciences capable of Demonstration" (IV.iii.18).

12 In the Reasonableness of Christianity, Locke considers just such a case in distinguishing the "matter" of the fact to be believed and the "manner" of the fact to be believed. "If it be a proposition concerning a matter of fact, it is enough to conceive, and believe the matter of fact. If it be a proposition concerning the manner of the fact, the manner of the fact must also be believed, as it is intelligently expressed in that proposition." For example, Locke continues, "he understands what is meant by the "dead shall rise.' For he can conceive, that the same man, who was dead and senseless, should be alive again...But none of [the] manner of [that] action [be] included in [that] proposition...But where the proposition is about the manner, the belief too must be of the manner, v.g. the article [of faith] is 'The dead shall be raised with spiritual bodies' and then the belief must be as well of this manner of the fact as of the fact itself" (Works VII: 240).

${ }^{13}$ I say "perhaps" here, since I am concentrating on original revelation, which Locke thinks can contain ideas that do not originate in sensation or reflection. Indeed, Locke seems to think Paul had such ideas: "Thus whatever things were discovered to St. Paul, when he was wrapp'd up in the Third Heaven; whatever Ideas his Mind there received, all the description he can make to others of that Place is only this, That there are such Things, as Eye hath not seen, not Ear heard, nor hath it entred into the Heart of Man to conceive" (IV.xvii.3). He is very clear, though, that the transmission of what has been originally revealed must be restricted: "Then, I say, That no Man inspired by GOD,
} 
Thus far the Dominion of Faith reaches, and that without any violence, or hindrance to Reason; which is not injured, or disturbed, but assisted and improved, by new Discoveries of Truth, coming from the Eternal Fountain of all Knowledge. (IV.xviii.10)

Proper or pure matters of faith, are not contrary to reason, but, to reiterate, are "above reason," consisting in propositions whose content we cannot (or hold that we cannot) judge or know the truth of based on evidence gained through our natural faculties of sensation, reflection, and reason. $^{14}$

We see another difference between faith proper and probability in that where intuitive and demonstrative knowledge would overrule a contrary judgment of faith we should assent to an evident matter of faith over a contrary probable judgment.

In all those Things therefore, where we have clear Evidence from our Ideas, and those Principles of Knowledge,...Reason is the proper Judge; and Revelation, though it may in consenting with it, confirm its Dictates, yet cannot in such Cases, invalidate its Decrees. (IV.xviii.10)

But since GOD in giving us the light of Reason has not thereby tied up his own Hands from affording us, when he thinks fit, the light of Revelation in any of those Matters, wherein our natural Faculties are able to give a probable Determination, Revelation, where God has been pleased to give it, must carry it, against the probable Conjectures of Reason. (IV.xviii.8)

Given this textual evidence, it is reasonable to conclude that Locke wants to distinguish "proper matters of faith" or "pure matters of faith" from the province of reason. So circumscribed we can see judgments of faith as something different from either knowledge or probability.

Importantly, Locke does not think that God would reveal a proposition contradicting something known intuitively or demonstratively, nor does such a proposition gain more certainty by also

can by any Revelation communicate to others any new simple Ideas which they had not before from Sensation or Reflexion" (IV.xviii.3). I thank Kenny Pearce for urging me to clarify this distinction.

${ }^{14}$ See Snyder (1986: 203): "Just as there is a body of propositions whose truth is discoverable only through natural faculties, there also is a body of propositions whose truth is discoverable only through faith. These propositions are revealed by God." Ashcraft (1969: 215) concurs: "The information we receive through faith... is not a part of our ordinary experience, and therefore, quite apart from the differences in the degree of certainty which we attach to any proposition so received, there is a difference in kind separating the information transmitted to us by God from that which we receive by any other means." Losonsky (2012: 706) seems also to agree, "For Locke, reason judges whether or not God revealed that $p$ even in cases where $p$ is a proposition 'Above Reason', that is, a proposition whose 'Truth or Probability' cannot be shown to be certainly true or probably true on the basis of experience, and where the fact that it was revealed that $p$ is the only available evidence for $p . "$ 
being revealed. Locke countenances neither divine undermining, nor through needless

redundancy duplicating, what we can come to know with the use of our natural faculties. For, as Locke says, "reason is natural revelation." ${ }^{, 15}$ It is also important clearly to distinguish faith in the content of a naturally undiscoverable proposition (one above reason) from knowledge or belief that the proposition has been revealed. Only evidence of the latter confers any additional certainty on the former. For justified assent to a revealed proposition, so far as we can understand or make sense of it, is dependent on justification by our natural faculties that the proposition actually has been revealed; it requires evidence that the proposition has its source in God. If we know or justifiably believe that, then we also know or justifiably believe that the proposition is true. Locke says, "Because though Faith be founded on the Testimony of God (who cannot lye) revealing any Proposition to us: yet we cannot have an assurance of the Truth of its being a divine Revelation, greater than our own Knowledge. Since the whole strength of the Certainty depends upon our Knowledge that God revealed it" (IV.xviii.5). Given that God, as infinitely good, cannot lie, having knowledge that God revealed the proposition fully justifies a claim to its truth. ${ }^{16}$ So, whether we can justify matters of faith - that we ought to believe them because they are revealed by God - is dependent on our natural faculties. Here Locke makes clear just this point:

15 "Reason is natural Revelation, whereby the eternal Father of Light, and Fountain of all Knowledge communicates to Mankind that portion of Truth, which he has laid within the reach of their natural Faculties: Revelation is natural Reason enlarged by a new set of Discoveries communicated by GOD immediately, which Reason vouches the Truth of, by the Testimony and Proofs it gives, that they come from GOD" (IV.xix.4). Note that this doesn't mean that God is precluded from revealing something, say, a moral truth, that conceivably we can discover on our own. Nuovo (2017: 216) explains that Locke's later turn toward religion to understand morality "does not require the abandonment of natural reason, rather its enlargement through revelation, not by endowing it with transcendent capacities, but by showing the reasonableness of extending belief to matters beyond the capacity of reason and experience to discover."

${ }^{16}$ Similarly, Losonsky (2012: 706) citing the same passage concludes, "This is an instance of the more general principle that the probability of the truth of a proposition does not exceed the probability of the evidence for it." Wolterstorff (1996: 79) employs a similar "principle of proportionality": "Adopt a level of confidence in the proposition which is proportioned to its probability on one's satisfactory evidence." 
I do not mean, that we must consult Reason, and examine whether a Proposition revealed from God can be made out by natural Principles, and if it cannot, that then we may reject it: But consult it we must, and by it examine, whether it be a Revelation from God or no: And if Reason finds it to be revealed from GOD, Reason then declares for it, as much as for any other Truth, and makes it one of her Dictates. (IV.xix.14)

Therefore, reason's role is to certify any purportedly non-natural communication as coming from God, not to assess the truth of the proposition as it stands on its own.

It is in this sense that faith is epistemically partnered with reason. As Locke explains, Faith is nothing but a firm Assent of the Mind: which if it be regulated, as is our Duty, cannot be afforded to any thing, but upon good Reason; and so cannot be opposite to it. He that believes, without having any Reason for believing, may be in love with his own Fancies; but neither seeks Truth as he ought, nor pays the Obedience due his Maker, who would have him use those discerning Faculties he has given him, to keep him out of Mistake and Errour. (IV.xvii.24)

Notice two important points in this passage. First, faith is a "firm assent of the mind," which given Locke's view on the nature of assent (or dissent) is a natural attitude we take toward a particular proposition on the basis of the evidence provided. In the earlier passage from IV.xviii.2, Locke tells us that what justifies assent to a proper matter of faith is not a deduction of reason, but the "credit [credibility] of the proposer." Because God cannot lie, God's credit is firmly established. Necessarily, if the proposition comes from God, it is true.

Second, even though an article of faith cannot be deduced by reason from ideas gained in sensation and reflection, the attitude of faith in a revealed proposition is supposed to be regulated by reason, which is why they are not opposed to one another. I take Locke to be saying that unless faith is subject to regulation by reason we have failed in our duty as rational creatures to use to the best of our ability the natural faculties we are given. So even though reason is not the source of a revealed proposition - of its content - it does seem to play a role on the back end as an epistemic gatekeeper of sorts to make sure that the proposition we claim to be true really is true, that we do have some sort of rational (or naturally discoverable) evidence for what we 
believe. That evidence comes from establishing the reliability of the "extraordinary way of communication" - that whatever is communicated really does come from God, whether directly or through an intermediary. That evidence establishes the credit of the proposer, and so justifies the truth of what we take to be revealed by justifying that it actually has been revealed.

It is worth emphasizing that in distinguishing "pure" or "proper" matters of faith I take Locke to be singling out propositions for which we could not have (or perhaps hold that we could not have) natural evidence. So the only evidence we could have is supernatural. As many of the passages in this section indicate, the distinction has more to do with the kind of evidence for the propositions assented to, than with the faculties employed. Were I to read a religious text I would be employing the same (natural) faculties as when I read a newspaper. But assenting to something allegedly revealed in the former is above reason (a judgment of "pure" faith), because natural evidence does not bear directly on the truth (or falsity) of the proposition revealed. Evidence for judgments of pure faith bears only on whether or not the proposition really is divinely revealed. For example, if the proposition is that we will be resurrected in a future state, I need to take into account evidence that the proposition has its source in divine revelation. Any evidence that, say, the revealed truth (that we will be resurrected) does not accord with my ordinary experience does not lessen its likelihood or appropriately weaken my assent.

\section{Justification for Revealed Propositions}

Before looking to what justifies the source of a revealed proposition, let's consider Locke's distinction between two kinds of revelation:

I say, Traditional Revelation, in distinction to Original Revelation. By the one, I mean that first Impression, which is made immediately by GOD, on the Mind of any Man, to which we cannot set Bounds; and by the other, those Impressions delivered over to others in Words, and the ordinary ways of conveying our Conceptions one to another. (IV.xviii.3) 
Original revelation is the immediate reception from God of some idea or notion (proposition or inclination) in the mind. Traditional revelation is the conveying to others through the use of words or other ordinary signs something that has been originally revealed. In thinking about questions of justification in Locke's religious epistemology, we might want to ask ourselves why Locke would think that anyone is justified in claiming to have received a direct communication from God. Why should Moses believe that God has spoken to him, that his inclination to go to Egypt to free his brethren came from God? And when Moses transmits God's message to the Pharoah, why should anyone believe it? As Locke says, why don't we instead treat these kinds of protestations as mere circular reasoning, that "all their Confidence is mere Presumption: and this Light, they are so dazzled with, is nothing, but an ignis fatuus that leads them continuously around in this Circle. It is a Revelation, because they firmly believe it, and they believe it, because it is a Revelation" (IV.xix.10)?

Locke answers that there is something extrinsic to the revelation itself, some "mark" or "outward sign" that convinces us that it is a case of revelation rather than enthusiasm: ${ }^{17}$

Thus we see the holy Men of old, who had Revelation from GOD, had something else besides that internal Light of assurance in their own Minds, to testify to them, that it was from GOD. They were not left to their own Perswasions alone, that those Perswasions were from GOD; But had outward signs to convince them of the Author of those Revelations. And to justify the Truth of their Commission from Heaven; and by visible Signs to assert the divine Authority of the Message they were sent with. Moses saw the Bush burn without being consumed, and heard a Voice out if it. This was something besides finding an impulse upon his Mind to go to Pharoah, that he might bring his Brethren out of Egypt: and yet he thought not this enough to authorize him to go with that Message, till GOD by another Miracle, of his Rod turned into a Serpent, had assured him of a Power to testify his Mission by the same Miracle repeated before them, whom he was sent to. (IV.xix.15)

Justification for Moses' belief that his instructions to go to Egypt come from God (an original revelation) is in the form of an additional sign - the bush burning without being consumed and a

\footnotetext{
${ }^{17}$ Locke distinguishes enthusiasm from both reason and revelation as "a third Ground of Assent... Which laying by Reason would set up Revelation without it" (IV.xix.3).
} 
voice coming from it. Moses' experience of the burning bush is evidence gained through his natural faculties that the original revealed proposition, or inclination, along with the "internal light of assurance" really does come from God. There was something else besides "an impulse upon his Mind" with its "internal persuasion" to go to Egypt. Notice that this was still not quite enough for Moses. Perhaps Moses questioned the veracity of his senses or whether anyone else would believe what he just saw and that the communication really was from God. So God established further its credibility (and Moses' authorization) with yet another miracle of his "Rod turned into a Serpent." Justification to convince the Pharoah that Moses was sent by God (establishing Moses's credibility in delivering a traditional revelation) is the repetition of his rod turning into a serpent. Surely, any claim to have received word from God would not be credible - not without something more to establish the credit. Miracles act as justifying premises in matters of faith, in a way analogous to the role of justification in demonstrative knowledge and probable judgment. $^{18}$

Therefore, we have structural similarity in Locke's accounts of knowledge, probable judgment, and matters of faith. In knowledge there is a cognitive achievement (the perception of an agreement of ideas) due to either non-inferential or inferential self-evidence and the certainty that comes with it. In probable judgment there is a cognitive achievement (taking there to be an agreement when one is not perceived) with the help of extraneous evidence resulting in an appropriate credence, or degree of assent. Similarly, in matters of faith there is a cognitive achievement (the receiving of revelation: an extraordinary way of communication/impulse upon the mind and an internal light of assurance) with the help of extraneous evidence resulting in an

\footnotetext{
${ }^{18}$ See again IV.xv.3-4. In the Third Letter Concerning Toleration, Locke affirms the "axial role" of miracles in judgments of faith. See Mooney and Improsciano (2005: 156). This is not to say that Locke would think that miracles are conclusive evidence of an instance of divine revelation. See also Wolterstorff (1994: 196), Jolley (2007: 451), and Losonsky (2012: 708).
} 
assent of faith. Now that we have established a general analogy between Locke's natural and religious epistemologies, I want to show that there is an even more robust structural similarity in the justification conditions for knowledge, probable judgment, and matters of faith. But first we should take a closer look at Locke's account of matters of faith (revelation) as justified by miracles.

\section{The Case of Miracles}

Locke has a short work called $A$ Discourse of Miracles, which was among the manuscripts Locke told Peter King could be published after his death. ${ }^{19}$ It opens with the definition:

A miracle then I take to be a sensible Operation, which being above the comprehension of the Spectator, and in his Opinion contrary to the establish'd Course of Nature, is taken by him to be Divine. He that is present at the fact is a Spectator: He that believes the History of the fact, puts himself in the place of the Spectator" (Locke 1706/2002: 44). ${ }^{20}$

Immediately noticeable is that Locke's definition is entirely subjective. Whether a sensible event counts as a miracle depends on whether it is taken to be one by the person witnessing the event. ${ }^{21}$ Upon seeing an unconsumed burning bush with a voice in it accompanying the revelation with its internal Light of assurance, and not comprehending how there can be a natural explanation, Moses believes the event to have a divine source; hence it counts as a miracle. ${ }^{22}$ Moses is given

\footnotetext{
${ }^{19}$ See Nuovo (2002: xxxvi) for the historical details.

${ }^{20}$ Note that the past or present performance of miracles can also lend credit to what is claimed to be an historical fact. For example, some of the Apostles performed miracles in the course of preaching of the resurrection of Jesus Christ and the revealed truth of his teachings.

${ }^{21}$ I don't mean to suggest that Locke would countenance that we simply take the experience of the event at face value without any additional consideration. Considering and rejecting causes other than divine would be part of concluding that there is no natural explanation.

${ }^{22}$ Locke defends the subjective nature of the definition by simply placing the burden of proof on the objector to find one that "is not liable to the same exception" (Locke 1706, 2002: 44). Hobbes's account of miracles includes a similar subjective criterion: "Furthermore, seeing admiration and wonder is consequent to [depends largely on] the knowledge and experience wherewith men are endued, some more, some less, it followeth that the same thing may be a miracle to one and not to another. And thence it is that ignorant and superstitious men make great wonders of those works which other men knowing to proceed from nature (which is not the immediate, but the ordinary of God), admire not at all..." (Leviathan: xxxvii, p. 294).
} 
evidence extraneous to his experience of the proposition/inclination revealed as justification that the revelation comes from God.

Moreover, Locke considers cases in which one's initial assessment changes with more evidence. One way to bolster the initial evidence is to provide yet another miracle as we saw in Moses' rod turning into a serpent just after he had seen the burning bush. Locke also considers this scenario:

For example, Jesus of Nazareth professes himself sent from God: He with a word calms a Tempest at Sea: This one looks on as a Miracle, and consequently cannot but receive his Doctrine: Another thinks this might be the effect of Chance, or Skill in the Weather and no Miracle, and so stands out; but afterwards seeing him walk on the Sea, owns that for a Miracle and believes: Which yet upon another has not that force, who suspects it may possibly be done by the assistance of a Spirit: But yet the same Person seeing afterwards our Saviour cure an inveterate Palsie by a word, admits that for a Miracle, and becomes a Convert...(Locke 1706/2002: 46).

Another way to bolster the evidence is to provide not only more miracles, but also more powerful miracles.

So, likewise the number, variety and greatness of the Miracles wrought for the confirmation of the Doctrine delivere'd by Jesus Christ, carry with them such strong marks of an extraordinary Divine Power, that the Truth of his Mission will stand firm and unquestionable, 'till any one rising up in opposition shall do greater Miracles than he and his Apostles did. (Locke 1706/2002: 47-48)

That Jesus and the Apostles performed more and better (more powerful) miracles is evidence that the message has a divine source. Genuine miracles attest to God's having revealed something because they "carry with them the evident marks of a greater Power than appears in opposition to it."

This removes the main Difficulty where it presses the hardest, and clears the matter from doubt, when extraordinary and supernatural Operations are brought to support opposite Missions, ...wherever there is an opposition, and two pretending to be sent from Heaven clash, the signs which carry with them the evident marks of a greater Power, will always be a certain and unquestionable evidence that the Truth and Divine Mission is on the side on which they appear. (Locke 1706/2002: 46-47) 
So we see that an event others take to be a miracle can be at first unconvincing or it can be contested by a competing extraordinary performance, in which case we should look to a greater number or the greater power as evidence of a divine source.

We can see Locke as having justification conditions operating from two different points of view: one from the point of view of an initial cognitive achievement and one from the point of view of revision or further regulation of our initial assent. ${ }^{23}$ Indeed, I will show how this meeting of epistemic conditions and the regulating role of reason accomplished thereby, is at the heart of Locke's epistemology generally. I will first consider the structural similarity between the operation of epistemic conditions in faith and what Locke calls "sensitive" knowledge of an external object. I will then consider those same conditions as operating in probable judgment. Finally, I will offer a consistent account of justificatory conditions in demonstrative and intuitive knowledge.

\section{Miracles and Sensitive Knowledge}

Two features of Locke's natural epistemology bear repeating. First, Locke's definition of knowledge includes what we might call a "subjective" or "first-personal" criterion - the perception of the agreement. Second, knowledge has three degrees of certainty: intuitive knowledge is the highest degree; demonstrative knowledge comes next; and sensitive knowledge has the lowest degree of certainty (IV.ii.14). Now there's a lot of controversy about how to

\footnotetext{
${ }^{23}$ What if the contest is not adjudicated satisfactorily? Locke has this reply: "Because it cannot be suppos'd God should suffer his Prerogative to be so far usurp'd by any inferior Being as to permit any Creature, depending on him to set his Seals, the marks of Divine Authority, to a Mission coming from him. For these supernatural signs being the only means God is conceived to have to satisfie Men as rational Creatures of the Certainty of any thing he would reveal, as coming from himself, can never consent that it should be wrested out of his hands, to serve the Ends and establish the Authority of an inferior Agent that rivals him" (Locke 1706/2002: 48-9). Essentially, God is not a being that is about to be one-upped.
} 
interpret sensitive knowledge. ${ }^{24}$ Nevertheless, I think the large majority of the scholarship can agree to the following basic commitments. We can see Locke as having a representational theory of ideas, ${ }^{25}$ as seeing sensitive knowledge as consistent with a definitional instance of knowledge (the perception of an agreement of ideas), ${ }^{26}$ as having our awareness of an idea's source in sensation play some sort of role in the account, ${ }^{27}$ and as seeing a set of probabilistic arguments in the IV.xi.4-7 also having a role to play. ${ }^{28}$

In Book IV chapter (ii) on the degrees of certainty of knowledge, Locke gives us an account of what happens in an instance of sensitive knowledge:

There can be nothing more certain, than that the Idea we receive from an external object is in our Minds; this is intuitive Knowledge. But whether there be any thing more than barely that Idea in our Minds, whether we can thence certainly infer the existence of any thing without us, which corresponds to that Idea, is that, whereof some Men think there may be a question made, because Men may have such Ideas in their Minds, when no such Thing exists, no such Object affects their Senses. But yet here, I think, we are provided with an Evidence, that puts us past doubting: For I ask any one, Whether he be not invincibly conscious to himself of a different Perception, when he looks on the Sun by day, and thinks on it by night; when he actually tastes Wormwood, or smells a Rose, or only thinks on that Savour, or Odour? We as plainly find the difference there is between any Idea revived in our Minds by our Senses, as we do between any two distinct Ideas. (IV.ii.14)

Here's a very bare bones picture that I think is consistent with many interpretations. First, we have an idea, say of the sun. We might want to ask whether we can know that there really exists a sun as the cause of the idea. But we have good evidence in the fact that we experience the idea

\footnotetext{
${ }^{24}$ For example, Allen (2013), Marušić (2016), Nagel (2016), Owen (2008), Priselac (2017), Rockwood (2013), Weinberg $(2013,2016)$, and Wilson (2014), (to mention a few) see sensitive knowledge as a form of knowledge rather than probable judgment. Newman (2007) argues that sensitive knowledge includes both kinds of cognitive acts. Rickless $(2008,2015)$ argues that sensitive knowledge is really a very high degree of assurance. I think the very broad-brushed account I am giving in this paper might still be consistent with Rickless in that he argues that an instance of sensitive knowledge is still the perception of a true proposition even if it doesn't count as knowledge.

${ }^{25}$ More recently, for example, Allen (2013), Marušić (2016), Nagel (2016), Newman (2007), Owen (2008), Priselac (2017), Rickless $(2008,2015)$, Weinberg $(2013,2016)$, and Wilson (2014).

${ }^{26}$ See note 25 .

${ }^{27}$ For example, Allen (2013), Nagel (2016), Owen (2008), Priselac (2017), Weinberg (2013, 2016), and Wilson (2014).

${ }^{28}$ Nagel (2016), Newman (2007), Priselac (2017), and Weinberg $(2013,2016)$ address the role of these arguments. I would think that the principle of charity would have to side with Locke's not having included them arbitrarily.
} 
as the result of sensation, and sensations are experienced differently from memories. Regardless of the number of different ways in which this story is told, much of the scholarship can agree that this is an account of an instance of sensitive knowledge consistent with the justificatory criterion for sensitive knowledge - the experience of a sensory idea, or the testimony of the senses, as part of the first-personal perception of the agreement of ideas consistent with the definition of knowledge. ${ }^{29}$ In addition, attendant to the perception of an agreement of ideas in any act of knowledge, for Locke, is an experience of certainty (IV.ii.2). In this case, because the perception of agreement also includes an experience of sensing, I think it is fair to say that we have a psychological experience in which we cannot but believe that there exists an external object as the cause of the experience. As Locke says in IV.ii.14, our consciousness of the idea experienced in sensing is evidence that "puts us past doubting."

But even if I have a convincing psychological experience as the result of perceiving the appropriate agreement, once I step back to question, taking a reflective stance to my initial cognitive state, I can generate a reason to doubt my initial experience of certainty. ${ }^{30}$ Perhaps I am being deceived by an evil demon or I am a brain in a vat. After all, once I step back to reflect, my cognitive state changes; I am no longer sensing. But then Locke provides more evidence (more reasons) to bolster (or further justify) our initial experience. He gives us a set of probabilistic arguments providing additional evidence that what we experience in sensing is the result of the real existence of an object. Those arguments point to our ability to be affected by the senses (IV.xi.4), the passivity of the senses (IV.xi.5), the fact that a sense experience is often

\footnotetext{
${ }^{29}$ This does not preclude that having sensitive knowledge may include the meeting of some sort of externalist justificatory condition as well. Wilson (2014) has what he calls a "hybrid" view. Nagel (2016), Newman (2007), and Weinberg (2016) add an externalist semantic condition to what is essentially an internalist account. Bolton (2004) argues that all that Locke successfully achieves is the meeting of an externalist semantic condition.

${ }^{30}$ Marušić (2016) argues that Locke is an infallibilist when it comes to sensitive knowledge, and so, I think, might be one to disagree.
} 
accompanied by a pain, while the memory of the very same experience is not (IV.xi.6), and that others are in common agreement that they are sensing something external (IV.xi.7). These are further reasons, from a different point of view, to support that we can continue to accept, albeit in the face of skeptical doubt, what we initially felt compelled to accept. Where the definitional criterion for sensitive knowledge includes justification from the point of view of an initial cognitive achievement, the probabilistic arguments provide additional justification from a reflective point of view, answering a skeptical question - a reason for doubt. ${ }^{31}$

We see the same epistemic structure at work in an instance of revelation, namely in Locke's account of the operation of miracles as evidence justifying our assent to a matter of faith something revealed in an extraordinary way of communication. Moses' initial experience of a miracle - the unconsumed burning bush - as evidence to justify his faith in the divine source of the revelation, when queried by him, is further justified through another miracle of the rod turning into a serpent. As we saw earlier, Locke explains that more miracles can be employed to bolster or secure conviction. Similarly, in Locke's account, a doubt can be raised when one claim to revelation justified by a miracle is contested by another:

Supernatural Operations attesting such a Revelation may with reason be taken to be Miracles, as carrying the marks of a superior and over-ruling Power, as long as no Revelation accompanied with marks of a greater Power appears against it. Such supernatural signs may justly stand good, and be receiv'd for Divine, i.e. wrought by a Power superior to all, 'till a Mission attested by Operations of a greater force shall disprove them. (Locke 1706/2002: 48-49) ${ }^{32}$

\footnotetext{
${ }^{31}$ In Descartes interpretation, there is a similar application of epistemic conditions to tease apart a difference in justification a clear and distinct idea would have before and after the Third Meditation proof for the existence of a non-deceiving God as a divine guarantor of our natural cognitive faculty. What has justification from an initial psychological point of view receives further justification (after the proof) from a metaphysical point of view. See, for example, Gewirth (1970), Curley (1978), Doney (1970), and DeRose (1992). How I see Locke as having dual justification conditions operating somewhat similarly, but also differently, will be argued in sections 6 and 7 . It is also important to note that, contrary to Descartes, any epistemic justification for Locke is achieved from with the limits of our natural faculties - what I am calling the regulating role of reason.

32 I suspect Locke would have to say that if another contender for messiah came around performing vastly more and more powerful miracles that did not conform to the teachings in the New Testament, then Locke would have to bite the bullet and accept the new messiah as a true messenger of God (as long as the teachings were in line with natural theology). In this light, it is interesting to think about the status of Islam. Although Muhammad claimed to perform
} 
As long as there arises no reason to question the divine source of the event, we are justified in our initial assent. But once there is a reason, we have to admit that perhaps we shouldn't continue to believe what we initially believed. We are then given additional justification in response to the challenge raised:

[T] he marks of a superior Power... always will be a visible and sure guide to Divine Revelation; by which men may conduct themselves in their examining of revealed Religions, and be satisfied which they ought to receive as coming from God. (Locke 1706/2002: 49)

His Power being known to have no equal, always will, and always may be safely depended on, to shew its superiority in vindicating his Authority, and maintaining every Truth that he has reveal'd. So that the marks of a superior Power accompanying it, always have been, and always will be a visible and sure guide to Divine Revelation[.] (Locke 1706/2002: 49)

In both cases, Locke is employing epistemic conditions at different stages of consideration. First, there is the meeting of the initial condition for faith - an extraordinary communication and a justifying miracle that it comes from God. As far as my education and experience extend and I can reasonably assess, I have no natural explanation for the event. But then the miracle may be questioned or contested giving me a reason to wonder, to reflectively question, whether I should continue to believe what I initially believed. To answer that question, I find support (or not) in additional justification: the marks of a superior power. ${ }^{33}$ Similar to an instance of sensitive

no miracles, and Locke (1706/2002: 45) states that Muhammad does not have the status of Moses and Christ, for he "pretends to no Miracles for the vouching his Mission" (to bring the Law), Muhammad did claim that Islam was founded on one, the Koran. I thank Victor Nuovo for raising these thought-provoking questions.

33 Along with a lack of explanation by natural means, Locke provides two other reasons to accept that an event issues from a superior power: "1. That no Mission can be look'd on to be Divine, that delivers any thing derogating from the Honour of the one, only, true, invisible God, or inconsistent with natural Religion and the rules of Morality... [;] 2. That it cannot be expected that God should send any one into the World on purpose to inform Men of things indifferent, and of small moment, or that are knowable by the use of their natural faculties" (Locke 1706/2002: 48). I take these to be additional reasons to further justify (or regulate) what we have initially subjectively concluded in a case of uncontested revelation. Moreover, the process of reflective questioning can (and probably should) continue, perhaps even throughout one's life. Years down the road as we come to learn more about the natural world we might conclude that what we once thought was a miracle really is not. See also Nuovo (2002: xxxvii).

With respect to (1) above, one might wonder whether, in the Old Testament, God's command to sacrifice Isaac was against the "rules of Morality"? Well, first, there was as yet no law, for that was revealed much later to Moses. But even so, wasn't the command against natural law as discoverable by reason? Locke seems not to address this 
knowledge we can see the operation of epistemic conditions operating from different points of view - the meeting of the initial condition (as contained in the definition) further supported by additional justification answering a reason to doubt.

Consider, now, that we are back in the Pharoah's house. Moses asserts that God has sent him to free his people. As evidence of divine revelation he throws down his rod, which turns into a serpent. Given my subjective experience I have no comprehension how this could happen by natural means. It's a miracle! Moses must be an emissary of God, so I assent in the manner of faith. But then the Pharaoh's magicians contest the miracle by doing the very same thing. And from their rods come blood and frogs too. I begin to reflectively question whether what I initially took to be a miracle really was one, whether my initial assent was warranted given that I now have a reason to doubt. But then Moses' serpent proceeds to clearly overpower the magicians' serpents, and more. ${ }^{34}$ Now I have this additional justification, something to bolster my belief, to justify that what I thought was a mark of divine power really is a mark of divine power. I have an additional reason to shore up my initial assent. Therefore, Locke's appeal to epistemic conditions from different cognitive perspectives in his account of miracles as evidence for matters of faith simply mirrors the operation of epistemic conditions in his account of sensitive

issue directly, but perhaps he can be seen to do so indirectly in the Reasonableness of Christianity when he describes the difference between the "Law of Works," which requires "compleat performance" and the "Law of Faith," which "is that Law whereby God Justifies a man for Believing, though by his Works he be not Just or Righteous" (Works VII: 15). Abraham's faith, according to the Law of Faith, justifies his actions, such that he achieves righteousness: "Rom. IV. 3. Abraham believed God [his promise to make of him a great nation through his issue], and it was counted to him for righteousness. V. 5. To him that believeth on him that justifieth the ungodly, his faith is counted for righteousness" (Works VII: 15). Perhaps we can see Abraham's faith as making righteous that which without that faith would not have been. Why, though, can't we apply the same principle to a psychotic person bent on killing another in the name of God? Locke's understanding of miracles as justifying the divine source of a command (an instance of revelation) can help to make this distinction. God promised Abraham (in another instance of revelation) that he would literally be the father of a new nation, even though Abraham was close to 100 years old and Sarah was far beyond childbearing age. And then Sarah conceived and bore Abraham's child, Isaac - a miracle by anyone's standards of the time. Just as God's covenant with Abraham was "above reason" and justified by a miracle, perhaps also was God's command to sacrifice Isaac. I thank Patrick Connolly for raising the initial question for me.

34 It helped that Moses also produced some lice, which the magicians could not replicate. After that, Locke says, "the decision was easie." 
knowledge. Consistent with the regulating role of reason in any act of assent, an initial conviction subject to a reason for doubt is reaffirmed (or not) by other (or more) reasons providing an answer to the question whether I should continue to assent to what I initially believed.

Indeed, Locke specifically mentions the role of reflection and regulation by reason (or lack thereof) in the case of enthusiasm. First, he gives us a definition of sorts - the meeting of an initial condition. Then he explains how that initial belief can be (and needs to be) reflectively questioned and constrained:

Their Minds being thus prepared, whatever groundless Opinion comes to settle it self strongly upon their Fancies, is an Illumination from the Spirit of GOD, and presently of divine Authority: And whatsoever odd Action they find in themselves a strong Inclination to do, that impulse is concluded to be a call or direction from Heaven, and must be obey'd; 'tis a Commission from above, and they cannot err in executing it... (IV.xix.6)

This I take to be properly Enthusiasm, which though founded neither on Reason, nor Divine Revelation, but rising from the conceits of a warmed or over-weening Brain, works yet, where it once gets footing, more powerfully on the Perswasions and Actions of Men, than either of those two, or both together:...For strong conceit like a new Principle carries all easily with it, when got above common Sense, and freed from all restraint of Reason, and check of Reflection, it is heightened into a Divine Authority, in concurrence with our own Temper and Inclination. (IV.xix.7, my emphasis in bold)

Where claims to revelation have justifying evidence initially and can stand up to reflective questioning due to additional evidence confirming what we initially believe, cases of enthusiasm do not. Indeed, the problem with enthusiasm is that it is not so regulated by reason.

\section{A Similar Justificatory Structure in Knowledge Proper and Probability}

Sensitive knowledge, due to its idiosyncracy, might be thought a bad example from which to argue that Locke's natural epistemology employs epistemic conditions in the way I have contended. I don't think so, though, for we see epistemic conditions operating similarly in both 
probability and what we might call "knowledge proper." First, let's consider probable judgment. We can see the same structure in Locke's account. Importantly, for Locke, there is an involuntary aspect to both knowledge and probable judgment - something over which we have no control. When we perceive an agreement we do not choose to be certain, nor do we voluntarily assign ourselves a degree of assent given the evidence for a probable judgment. We just see the agreement (the truth) and experience certainty; in probable judgment we just naturally presume the proposition to be true to a degree warranted by how we are affected by the evidence. This is not to say that we have no epistemic responsibility when it comes to what we know and believe. We do, and some of that has to do with the regulating role of reason in both our initial assent and in questioning (or in responding to additional evidence) whether what gains our assent is as warranted as we initially think it is.

As with matters of faith, where miracles justify assent to a revealed proposition, probable judgments are justified by something, as Locke says, "extraneous to," something "not evidently joined on both sides to," the thing believed (IV.xv.3). Appeal is made to something outside (or not internally connected to) the individual ideas constituting the proposition to justify assent to the proposition. Similar to an instance of sensitive knowledge and a judgment of faith there is an initial assent meeting the epistemic condition defining that particular cognitive achievement. In knowledge there is assent to a proposition due to the appropriate evidence (the perception of an agreement of ideas); in a judgment of faith there is assent to a (revealed) proposition/inclination due to the appropriate evidence (a miracle); and also in a probable judgment there is assent to a proposition due to the appropriate evidence (our own experience or the testimony of another): Probability then, being to supply the defect of our Knowledge, and to guide us where that fails, is always conversant about Propositions, whereof we have no certainty, but only some inducements to receive them for true. The grounds of it are, in short, these two following: 
First, The conformity of any thing with our own Knowledge, Observation, and Experience.

Secondly, The Testimony of others, vouching their Observation and Experience. In the Testimony of others, is to be considered, 1. The Number. 2. The Integrity. 3. The Skill of the Witnesses. 4. The Design of the Author, where it is Testimony out of a Book cited. 5. The Consistency of the Parts, and Circumstances of the Relation. 6. Contrary Testimonies. (IV.xv.4)

In the first case, our own experience and observation, and in the second, the testimony of another, are the inducements to take the proposition to be true. How well the proposition conforms to our own experience or to the testimony of another's experience determines the degree to which we initially assent. Locke lists a number of criteria to consider in assessing the experience and testimony of another. We should consider the integrity of the testifier (whether a person or a publication), the number of testifiers agreeing to the testimony, the skill of the witness to an event, and whether a testifier has a "design," which I take to be a motive, interest, or ill use of rhetoric in promoting a particular belief. All of these considerations would weigh in any probable judgment justified by testimony.

But then Locke clearly distinguishes judgment from what he calls "right judgment." One rightly judges "with care and fairness, [has] sifted the Matter as far as they could; and that they have searched into all the Particulars, that they could imagine to give any Light on the Question" (IV.xvi.1). Right judgment requires that we take into account all the evidence available including any disconfirming experiences or testimony, "to sift the matter as far as we can," with the result that we assent accordingly. Although initially we may achieve right judgment, Locke seems to think that more often we do not. Rather, judging rightly seems to require that we question our beliefs, by taking a reflective stance, to make sure that the degree to which we initially assent is proportionate to all the evidence available:

May we not find a great number (not to say the greatest part) of Men, that think they have formed right Judgments of several matters; and that for no other reason, but because they never thought otherwise? That imagine themselves to have judged right, only because they never 
questioned, never examined their own Opinions?...But in matters of Probability, 'tis not in every case we can be sure, that we have all the Particulars before us, that any way concern the Question; and that there is no evidence behind, and yet unseen, which may cast the Probability on the other side, and out-weigh all, that at present seems to preponderate with us. (IV.xvi.3)

As Locke enjoins us, once we have made a judgment, rather than hold on to it too tightly, we should subject it to scrutiny, to further rational regulation. Such questioning of what we believe, being open to new evidence or a revised assessment of the reliability of the testimony of another, may give us a reason to doubt the strength of a belief or whether we should jettison it all together. Similar to what happens when we assent to a revealed proposition/inclination, or in an instance of sensitive knowledge, our initial assent to the proposition should be modified - either bolstered or diminished - by the addition of further confirming or disconfirming evidence. By employing epistemic conditions from different perspectives or points of view, Locke ensures that reason regulates the degree to which we assent to propositions such that our beliefs are appropriately supported by the available evidence. ${ }^{35}$

What about demonstrative and intuitive knowledge? Here, too, or so I will argue, we can see epistemic conditions operating at both an initial and a reflective point of view. Just as probable judgments admit of degrees of assent (e.g. confidence, conjecture, wavering, distrust, etc.), Locke thinks that intuitive and demonstrative knowledge (and sensitive knowledge) have different degrees of certainty. On the one hand, intuitive knowledge, with the highest degree of certainty, is immediate and self-evident:

For in this the Mind is at no pains of proving or examining, but perceives the Truth, as the Eye doth light, only by being directed toward it. Thus the Mind perceives, that White is not Black,

\footnotetext{
35 This brings up an interesting question as to what Locke's ethics of belief requires. See Wolterstorff (1996: 85-86) for the rather strong view that it requires "doxastic self-mastery," a form of continual self-examination or doxastic self-discipline by which we rid ourselves of any prejudices or biases that might lead us into doxastic wrong-doing. See also Schouls (1992). Such a stringent requirement might seem excessively demanding. A virtue of my interpretation is that it opens the door to a less demanding (and perhaps more plausible) requirement that doxastic virtue requires reflectively considering beliefs when they are challenged or when a reason to doubt a particular belief becomes salient.
} 
That a Circle is not a Triangle, That Three are more than Two, and equal to One and Two. Such kind of Truths, the Mind perceives at the first sight of the Ideas together, by bare Intuition, without the intervention of any other Idea; ... This part of Knowledge is irresistible, and like the bright Sun-shine, forces it self immediately to be perceived, as soon as ever the Mind turns its view that way; and leaves no room for Hesitation, Doubt, or Examination, but the Mind is presently filled with the clear Light of it. (IV.ii.1)

Intuitive knowledge, as Locke says, forces itself upon us as soon as we perceive the juxtaposition of the ideas in the mind, and, importantly, there is "no room for Hesitation, Doubt, or

Examination..."

On the other hand, successful demonstrations, having the next (lesser) degree of certainty, are composed of internally connected intuitively known steps, each with the highest degree of certainty. Nevertheless, Locke thinks demonstrative knowledge is less certain. Why? What would explain why a series of intuitively known steps is less certain than just one of those steps? Consider this passage:

By which it is plain, that every step in Reasoning, that produces Knowledge, has intuitive Certainty; which when the Mind perceives, there is no more required, but to remember it to make the Agreement or Disagreement of the Ideas, concerning which we enquire, visible and certain. So that to make any thing a Demonstration, it is necessary to perceive the Agreement of the intervening Ideas, whereby the Agreement or Disagreement of the two Ideas under Examination (whereof the one is always the first, and the other the last in the Account) is found. This intuitive Perception of the Agreement or Disagreement of the intermediate Ideas, in each Step and Progression of the Demonstration, must also be carried exactly in the Mind, and a Man must be sure that no part is left out; which because in long Deductions, and the use of many Proofs, the Memory does not always so readily and exactly retain: therefore it comes to pass, that this is more imperfect than intuitive Knowledge, and Men often embrace Falshoods for Demonstrations. (IV.ii.7)

In demonstrative knowledge, the perception of the agreement between the original ideas requires intervening ideas. Once all the intuitively known steps are laid out the agreement is "visible and certain": the progression of steps has been completed. The reason demonstrative knowledge is less certain than intuitive knowledge is that reflectively questioning whether my certainty is warranted to the degree I think it is, can generate a reason to doubt. Because the demonstration is 
long, I have had to rely on my memory to hold the proof together as I move from step to step.

It's possible that I have not exactly retained a step or I may even have left a step out. Such a

reason to doubt may lead me to look to external reasons to bolster my security in my own feeling

of certainty. I may ask a friend to check the proof or I may look up the proof to find

confirmation. Nevertheless, that anyone must resort to long and complicated proofs to assent to a

proposition will result in the same reason for doubt and so the same lessened degree of certainty

- namely the degree of certainty to which we can appropriately claim justification. ${ }^{36} 37$

Need we now worry about the analogy carrying over to simple demonstrations? I think not.

Indeed, it seems consistent with Locke's view that were we able to have all the steps of the proof

in the mind simultaneously we would not be able to generate a reason to doubt. Perhaps I have

taught the Essay enough times that I will never forget the intervening idea in knowing

demonstratively that "the angles of a triangle are equal to two right angles." Because all the ideas

necessary to show the agreement are there present to my mind, the perception of the agreement is

${ }^{36}$ Descartes too, in Rules for the Direction of the Mind, considered demonstrative knowledge as more vulnerable to mistake because of its reliance on memory. In "Rule Eleven," Descartes distinguishes between a deduction that "involves a kind of movement of our mind" and one that "no longer signifies a movement but rather the completion of a movement":

As we have said, conclusions which embrace more than we can grasp in a single intuition depend for their certainty on memory, and since memory is weak and unstable, it must be refreshed and strengthened through this continued and repeated movement of thought. Say, for instance in virtue of several operations, I have discovered the relation between the first and the second magnitude of a series, then the relation between the second and the third and the fourth, and lastly the fourth and the fifth: that does not necessarily enable me to see what the relation is between the first and the fifth, and I cannot deduce it from the relations I already know unless I remember all of them. That is why it is necessary that I run over them again and again in my mind until I can pass from the first to the last so quickly that memory is left with practically no role to play, and I seem to be intuiting the whole thing at once. (CSM I: 38; AT X: 408-9). See also (CSM I: 37; AT X: 408).

Descartes's point here, not unlike Locke's, is that although deduction itself is a mental faculty that leads to certainty, the less of a role memory has to play in constructing the proof, namely the more able we are to perceive the whole proof at once, the greater is our justification for certainty. (There is some controversy whether Locke would have read the Rules prior to formulating his epistemology. It is not controversial, however, that Arnauld had read and incorporated them, and Locke was highly influenced by the Port Royal logic. See Ayers (1991); Nuchelmans (1998); Van der Schaar (2008); Marŭsić (2014); and Pearce (2017).)

37 Notice also how clearly the analogy between Locke's account of demonstrative knowledge and judgments of faith shows up. Knowledge can be infallible (as successful demonstration is) and yet leave room for doubt upon reflective consideration, because one can doubt whether one has really performed a demonstration. Similarly, divine revelation is infallible, and yet one might doubt whether something is divinely revealed. 
immediate. This would be just like a case of intuitive knowledge, in which we cannot generate a reason for doubt. ${ }^{38}$ Because all of the ideas needed to perceive the agreement are present to the mind simultaneously, having intuitive knowledge is a cognitive situation in which reflective questioning does not reveal a reason for doubt. For to reflectively question the certainty of an intuitively perceived agreement is simply to perceive that agreement all over again. For example, were I reflectively to consider whether I know that white is not black, I will be in the same position I was initially; I will immediately perceive the same proposition - "white is not black," namely the same agreeing (or disagreeing) ideas all over again. I cannot get myself into a cognitive situation in which I can generate a doubt with respect to my intuitive knowledge. As we saw above, "there is no room...for Doubt" (IV.ii.1). Locke says, "He that demands a greater Certainty than this [intuitive knowledge] demands he knows not what, and shews only that he has a Mind to be a Sceptick, without being able to be so" (IV.ii.1, my emphasis). So, it is the ability of intuitively perceived agreements to withstand reflective scrutiny that gives intuitive knowledge the highest degree of certainty. And the extent to which the other two species of knowledge (demonstrative and sensitive) also stand up to rational regulation determines their respective ranks in Locke's epistemology of degrees of certainty of knowledge.

On the one hand, we can see sensitive knowledge as having the least degree of certainty because, even though it meets the epistemic condition for knowledge, it does not stand up to reflective scrutiny all that well. When I reflectively question the initial force of certainty in perceiving the agreement of ideas (the cognitive achievement in knowledge), I can generate a

\footnotetext{
38 Analogously, Locke describes Paul's certainty of the cogency of the teachings in the Gospel, because he received it from God all at once and "so it lay all clear in order open to his view...' tis plain 'twas a Matter he was perfectly Master of: he fully possess'd the entire Revelation he had receiv'd from God, had thoroughly digested it; all the Parts were formed together in his Mind into one well contracted harmonious Body. So that he was no way in any Uncertainty" (Locke 1823: 19). I take Locke here to be noting Paul's full understanding of the whole of the Doctrine because it lay fully open to him in his mind in a way analogous to all the premises of a demonstration. There would be no room for uncertainty in either case.
} 
rather comprehensive doubt. Reflective scrutiny reveals the possibility that I am entirely mistaken about the causes of my ideas experienced in sensation. My brain, after all, might be wired up to electrodes. Therefore, regardless of my initial experience of certainty in perceiving the agreement of ideas, rational regulation requires that I admit the possibility of a systematic failure of my cognitive faculty in sensing. On the other hand, demonstrative knowledge fares better. Even though I can raise a doubt as to whether I have correctly demonstrated a given agreement of ideas, it is not the case that reflective questioning results in a wholesale doubt as to my rational ability to construct a proof. As we saw earlier, I can construct rational proofs in which I can perceive all the connections simultaneously, and thus not generate a reason to doubt. Reason justifies both its scope and reliability from within its own limitations.

Locke's accounts of knowledge, probable judgment, and faith, in the employment of epistemic conditions from both an initial and a reflective point of view, therefore, confirms the structural similarity throughout all of Locke's epistemology. Regardless of whether what we claim to know or judge originates in our natural faculties of sensation or reflection or in a divine communication, in each case, there is an initial cognitive achievement including an initial measure of assent based on the evidence appropriate to that kind of cognition. Also in each case, that initial assent can be subjected to rational regulation, to make sure that what we initially take to be true warrants the certainty, the probability, or the faith we initially experience. Subjecting our cognitive achievements in knowledge, probability, and faith to such rational regulation epitomizes, I believe, Locke's attempt in the Essay, from within the limits of our own natural faculties, to discover the scope and reliability of our epistemic accomplishments. As such, it makes sense that Locke would say that "Reason must be our last Judge and Guide in every Thing" (IV.xix.14). 


\section{Conclusion}

I have argued that Locke's natural epistemology employs epistemic conditions from different perspectives or cognitive situations. Consistent with this account, I have argued that Locke's religious epistemology does the same. In both, there is appeal to justification from two standpoints: from an initial point of view meeting the definition of knowledge, probability, or faith resulting in our assent; and from a further reflective point of view answering the question whether the strength of our initial assent is fully warranted. How well each instance of knowledge, probability, or faith, when questioned, stands up to reflective scrutiny adjusts (or not) the degree to which our assent is actually warranted given the available evidence. In so arguing, I have outlined a new interpretation of the ground and coherence of Locke's epistemology, one that acknowledges and accounts for Locke's view that ultimately any confirmation (or guarantee) of our epistemic achievements must come from within the justificatory limitations of what our natural faculties can deliver, namely what I, following Locke, have called the regulating role of reason. ${ }^{39}$

${ }^{39}$ Many thanks to Patrick Connolly, Victor Nuovo, Kenny Pearce, Helga Varden, and three anonymous referees for Journal of the History of Philosophy for very helpful conversations and comments at different stages of the paper. Thanks also to those attending a Philosophy Department Colloquium at the University of Minnesota, Twin Cities, in 2018, a colloquium session at the Pacific Division Meeting of the APA in 2017, and the Locke Workshop at CUNY, Graduate Center, in 2016. 
Works Cited

Allen, Keith (2013). "Locke and Sensitive Knowledge." Journal of the History of Philosophy $51: 2,249-256$.

Ashcraft, Richard (1969). "Faith and Knowledge in Locke's Philosophy." In ed. John Yolten, John Locke: Problems and Perspectives. Cambridge: Cambridge University Press, 194-223.

Ayers, Michael (1991). Locke, 2 vols. London and New York: Routledge.

Bolton, Martha Brandt (2004). "Locke on the Semantic and Epistemic Role of Ideas." Pacific Philosophical Quarterly 85:3, 301-21.

Curley, Edwin (1993). "Certainty: Psychological, Moral, and Metaphysical.” In ed. Stephen Voss, Essays on the Philosophy of Science of Rene Descartes. Cambridge, MA: Harvard University Press, 569-597.

Descartes, Renes (1984). The Philosophical Writings of Descartes, 3 Vols. Translated and Edited by J. Cottingham, R. Stoothoff, D. Murdoch, A. Kenny. Cambridge: Cambridge University Press.

DeRose, Keith (1992). "Descartes, Epistemic Principles, Epistemic Circularity, and Scientia." Pacific Philosophical Quarterly 73:3, 220-238.

Doney, Willis (1970). Descartes' Conception of Perfect Knowledge." Journal of the History of Philosophy 8, 387-403.

Gewirth, Alan (1970). “The Cartesian Circle Reconsidered.” Journal of Philosphy 67:19, 668685 .

Hobbes, Thomas (1994). Leviathan. Edited by Edwin Curley. Indianapolis/Cambridge: Hackett Publishing Co.

Jolley, Nicholas (2007). “Locke on Faith and Reason.” In ed. Lex Newman, The Cambridge Companion to Locke's Essay. Cambridge: Cambridge University Press.

Locke, John (1975). An Essay concerning Human Understanding, Fourth Edition. Edited by P.H. Nidditch. Oxford: Clarendon Press.

------ (1823). The Works of John Locke, 10 vols. London.

------ (1823). A Paraphrase and Notes on the Epistles of St. Paul to the Galatians, First and Second Corinthians, Romans, Ephesians: To which is prefixed, an essay for the understanding St. Paul's Epistles, by consulting St. Paul himself. London: Printed for Thomas Tegg; W. Sharpe 
and Son; G. Offor; G. and J. Robinson; J. Evans and Co.: Also R. Griffin and Co. Glasgow; and J. Cumming, Dublin.

(1706, 2002). A Discourse of Miracles. In The Posthumous Works of John Locke (London). In ed. Victor Nuovo, John Locke: Writings on Religion. Oxford: Oxford University Press.

------ (1687/2002). Immediate Inspiration. BOD MS Locke c. 27, fos. 73-74. In ed. Victor Nuovo, John Locke: Writings on Religion. Oxford: Oxford University Press.

Losonsky, Michael (2012). "Locke and Leibniz on Religious Faith." British Journal for the History of Philosophy 20:4, 703-721.

Marusǐć, Jennifer Smalligan (2016). “Locke’s Simple Account of Sensitive Knowledge.” Philosophical Review 125:2, 205-239.

------ (2014). "Propositions and Judgments in Locke and Arnauld: A Monstrous and Unholy Union?" Journal of the History of Philosophy 52:2, 255-80.

Mooney, T. Brian and Imbrosciano, Anthony (2005). "The Curious Case of Mr. Locke's Miracles." International Journal for the Philosophy of Religion 57:3, 147-168.

Nagel, Jennifer (2016). "Sensitive Knowledge: Locke on Skepticism and Sensation." In ed. Matthew Stuart, The Blackwell Companion to Locke. West Sussex, UK: Blackwell Publishing, 313-333.

Newman, Lex (2007). “Locke on Knowledge.” In ed. Lex Newman, The Cambridge Companion to Locke. Cambridge: Cambridge University Press, 313-51.

Nuchelmans, Gabriel (1986). "The Historical Background to Locke’s Account of Particles." Logique et Analyse 29: 53-71.

Nuovo, Victor (2017). John Locke: The Philosopher as Christian Virtuoso. Oxford: Oxford University Press.

------ (2002). John Locke: Writings on Religion. Oxford: Oxford University Press.

Owen, David (2008). "Locke on Sensitive Knowledge."

(http://www.ic.arizona.edu/ic/dwo/David\%27s\%20Papers/SensKn1.rtf).

Pearce, Kenneth L. (2017). "How Berkeley Gardener Knows His Cherry Tree.” Pacific Philosophical Quarterly 98 (S1), 553-576.

Priselac, Matthew (2017). Locke's Science of Knowledge. New York and London: Routledge. 
Rickless, Samuel C. (2015). “Locke's 'Sensitive Knowledge': Knowledge or Assurance?" Oxford Studies in Early Modern Philosophy 7.

------. (2008). “Is Locke's Theory of Sensitive Knowledge Inconsistent,” Philosophy and Phenomenological Research 77:1, 83-104.

Rockwood, Nathan (2013). “Is Sensitive Knowledge 'Knowledge'?” Locke Studies, 13, 15-30.

Schouls, Peter (1992): Reasoned Freedom: John Locke and the Enlightenment. Ithaca: Cornell University Press.

Snyder, David C. (1986). "Faith and Reason in Locke's Essay." Journal of the History of Ideas 47: 2, 197-213.

Van der Schaar, Maria (2008). "Locke and Arnauld on Judgment and Proposition." History and Philosophy of Logic 29, 327-41.

Weinberg, Shelley (2016). Consciousness in Locke. Oxford: Oxford University Press.

-------. (2013). “Locke’s Reply to the Skeptic.” Pacific Philosophical Quarterly 94, 389-420.

Wilson, Aaron Bruce (2014). “Locke’s Externalism About Sensitive Knowledge.” British Journal for the History of Philosophy 22:3, 425-45.

Wolterstorff, Nicholas (1996). John Locke and the Ethics of Belief. Cambridge: Cambridge University Press. 